\title{
CRIAÇÃO DE VALOR DAS CORPORAÇÕES INDUSTRIAIS NO BRASIL: UMA ANÁLISE PARA O PERÍODO 2000-2017
}

\author{
Bruna B. Lopes*, Rodrigo Lanna Franco da Silveira
}

\begin{abstract}
Resumo
O presente estudo avaliou a evolução da criação de valor das companhias industriais brasileiras de capital aberto nas décadas de 2000 e 2010. Explorou-se ainda a agregação de valor conforme o setor da indústria, comparando as diferenças do retorno sobre o investimento (ROI) obtido. De forma a atingir tais objetivos, a pesquisa utilizou dados econômico-financeiros das companhias brasileiras. Verificou-se uma queda de cerca de $40 \%$ do ROI entre 2005 e 2017, sendo os setores de média e alta intensidade tecnológica os mais impactados, indicando uma forte destruição de valor. Os resultados das estimações dos modelos de dados em painel apontaram que as variáveis liquidez, giro do ativo, margem líquida e tamanho se mostraram estatisticamente significativas para explicar o comportamento do ROI das indústrias, tendo ênfase especial a variável binária de recessão econômica do período 2014-2016.
\end{abstract}

\section{Palavras-chave: indústria nacional, valor econômico agregado, retorno sobre o investimento}

\section{Introdução}

A pesquisa utilizou como referência o modelo de Gestão Baseada em Valor (GBV), o qual possui a criação de valor para seus acionistas como principal objetivo, além de incluir, diferentemente da Contabilidade tradicional, o custo de oportunidade do capital em seus cálculos (Assaf, 2016). Ressalta-se ainda que esse modelo de gestão destaca, como principal medida de desempenho, o Valor Econômico Agregado (VEA), indicador que permite avaliar se a empresa está agregando ou destruindo valor.

Diante do desempenho da indústria nacional nas décadas de 2000 e 2010 , em que se constata um grande debate em torno da existência do fenômeno da desindustrialização no país, o estudo propõe analisar a evolução da geração de valor deste setor entre 2005 e 2017.

\section{Metodologia, Resultados e Discussão}

A amostra do estudo compreende 111 companhias industriais brasileiras de capital aberto, divididas em setores de alta, média-alta, média-baixa e baixa intensidade tecnológica (IBGE, 2016). Utilizou-se modelo de dados em painel, aplicando o Método dos Mínimos Quadrados Ordinários para estimação, em que a variável dependente foi o Retorno sobre o Investimento (ROI), devido à sua forte relação com o VEA das empresas.

Ao analisar a evolução do ROI durante o período 20052017, constata-se uma trajetória descendente, com um forte declínio no período da recessão econômica do país de 2014 a 2016 (Gráfico 1). Com relação aos setores, divididos a partir do grau de intensidade tecnológica, nota-se que todos foram impactados pela recessão, especialmente os de alto e médio-alto grau.

Os resultados das estimações do modelo de dados em painel (Tabela 1) indicam que a variável binária relativa à recessão tem forte influência negativa sobre a rentabilidade das indústrias. Além disso, as estimações apontam que as variáveis liquidez, giro do ativo, margem líquida e tamanho se mostraram estatisticamente significativas para explicar o comportamento do ROI das indústrias. Adicionalmente, o setor de média-baixa intensidade mostrou um $\mathrm{ROI}$ superior em relação ao setor de baixa intensidade.
Gráfico 1. Evolução do ROI das companhias industriais brasileiras entre 2005 e 2017

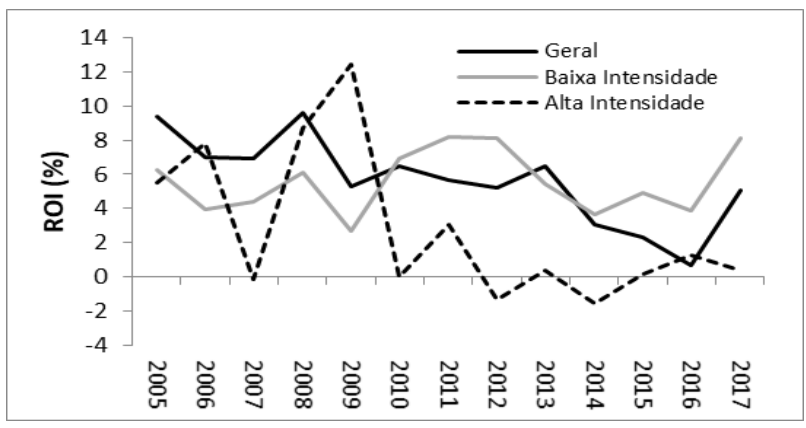

Tabela 1. Resultados das estimações

\begin{tabular}{|lrr|}
\hline Variável & Coeficiente & p-Valor \\
\hline Constante & $-20,409$ & 0,000 \\
Endividamento & 0,012 & 0,378 \\
Liquidez Corrente & 1,189 & 0,000 \\
Giro do ativo & 7,585 & 0,000 \\
Margem Líquida & 0,037 & 0,000 \\
Ln(Ativo) & 1,241 & 0,000 \\
Recessão (2014-2016) & $-3,762$ & 0,000 \\
Alta intensidade & 0,633 & 0,596 \\
Média-alta intensidade & $-0,569$ & 0,586 \\
Média-baixa intensidade & 1,997 & 0,047 \\
\hline
\end{tabular}

\section{Conclusões}

Verificou-se uma queda de cerca de $40 \%$ do $\mathrm{ROI}$ das corporações industriais de capital aberto no Brasil entre 2005 e 2017. Além disso, as estimações econométricas mostram o impacto negativo da recessão econômica, enfrentada pelo país entre 2014 e 2016, sobre a rentabilidade destas empresas, evidenciando, assim, um quadro de forte destruição de valor neste setor.

\section{Agradecimentos}

Os autores agradecem ao CNPq pelo suporte financeiro concedido ao projeto e pela oportunidade de aprendizado e inserção no ambiente de pesquisa.

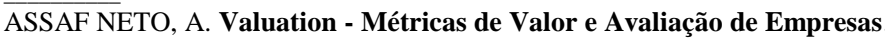
São Paulo, Atlas, 2016.

IBGE - Instituto Brasileiro de Geografia e Estatística. Pesquisa Industrial Anual. Rio de Janeiro, 2016. 